\title{
Conformation of Sterically Hindered 4-Methyl-2-oxo-2-trityl- 1,3,2-dioxaphosphorinane in the Solid State and the Solution
}

\author{
R. Kruszynski $\cdot$ E. Czubacka $\cdot$ A. Trzesowska-Kruszynska • \\ T. J. Bartczak $\cdot$ K. S. Bruzik $\cdot$ P. Knopik • \\ Z. Kudzin - W. J. Stec • W. M. Wolf
}

Received: 14 January 2011/Accepted: 15 April 2011/Published online: 30 April 2011

(C) The Author(s) 2011. This article is published with open access at Springerlink.com

\begin{abstract}
The cis- and trans-2-methyl-2-oxo-2-trityl1,3,2-dioxaphosphorinanes were obtained in the Arbuzov reaction of 2-methoxy-4-methyl-1,3,2-dioxaphosphorinane with trityl chloride. The NMR spectra $\left({ }^{1} \mathrm{H},{ }^{13} \mathrm{C}\right.$ and $\left.{ }^{31} \mathrm{P}\right)$ in solution indicated that trans isomer exists in the form of two noncongruent molecules and it adopts two different conformations: a halfchair and a sofa, while the cis isomer exists as the mixed half/chair-sofa conformer. The compounds crystallise as a pure chiral forms and as a racemates. The solid state structural studies show that NMR data are consistent with the single crystal X-ray analysis, but the conformation existing in the crystal structure is more complex than it can be supposed on sole NMR determination. Crystal data: cis-isomer chiral form: space group $P 3_{2}, a=8.782, b=8.782, c=21.680, \alpha=90.00$, $\beta=90.00, \gamma=120.00, V=1448.0$; cis-isomer racemate:
\end{abstract}

R. Kruszynski $(\varangle) \cdot$ E. Czubacka ·

A. Trzesowska-Kruszynska - T. J. Bartczak - W. M. Wolf Institute of General and Ecological Chemistry, Technical University of Lodz, Zeromskiego 116, 90-924 Lodz, Poland e-mail: rafal.kruszynski@p.lodz.pl

\section{K. S. Bruzik}

Department of Medicinal Chemistry and Pharmacognosy, University of Illinois at Chicago, 833 South Wood Street, Chicago, IL, USA

P. Knopik - W. J. Stec

Center of Molecular and Macromolecular Studies, Polish Academy of Sciences, Sienkiewicza 112, Lodz, Poland

\section{Z. Kudzin}

Department of Organic Chemistry, University of Lodz, Narutowicza 68, Lodz, Poland space group $P c a 2_{1}, a=16.773, b=8.491, c=27.006$, $\alpha=90.00, \beta=90.00, \gamma=90.00, V=3846.2$; trans-isomer racemate: space group $C c, a=16.133, b=8.388$, $c=16.158, \quad \alpha=90.00, \quad \beta=117.20, \quad \gamma=90.00, \quad V=$ 1944.8; trans-isomer chiral form: space group $P 1, a=$ 8.397, $b=9.003, \quad c=14.944, \alpha=80.76, \quad \beta=74.38$, $\gamma=63.31, V=971.1)$.

Keywords Dioxaphosphorinane - Crystal structure · NMR

\section{Introduction}

The organophosphorus compounds are renowned for their diverse physiological activities. Among these the posphonate moiety is an important pharmacophore in the pharmaceutical chemistry [1-6] and can be used as a building block for antibiotics [7-10], herbicides [11, 12], insecticides [13], fungicides [14] and anti-viral agents [15]. Additionally, the phosphonic acids and their derivatives may be considered as long life analogues of transition states for tetrahedral intermediates in amide/ester hydrolysis [16]. Among others, these compounds also possess enzyme inhibition properties and consequently they can serve as antibacterial and anticancer drugs [17-31]. Phosphorylated alkenes are also synthetically useful [32-35] and are commonly used in organic synthesis [36-40].

In recent years, several six-membered ring phosph(on)ates and phosphonamides have been reported as potent prodrugs against liver diseases such as hepatic $\mathrm{B}$ and $\mathrm{C}$ and also as antitumor agents [41]. Conformations of six-membered rings themselves and in reference to their biological activity has been lately widely studied and reviewed [42]. The cyclic phosphonates are required intermediates in 
multiple organic reactions [43-48] and they are used as chiral synthons [49]. Bisphosponate compounds are still under study by pharmaceutical and other industrial companies because of their potential medical [49] or technical applications (e.g. pentaerythritol diphosphonate is capable of being used as a fire retardant agent and as a plasticizer [50]).

The 1,3,2-dioxaphosphorinane derivatives, an important class of organophosphorus heterocycles, are interesting compounds because of their biological activities, particularly in reference to the design of enzyme inhibitors [5158]. As a part of organophosphorus compounds the 1,3,2dioxaphosphorinanes are also very important in pesticide and medicinal science, owing to their wide biological activities and stereochemistry [59]. The conformation of heterocyclic 1,3,2-dioxaphosphorinane ring of the cyclic phosphate and phosphonate esters has been the subject of vigorous research in the past [60-62]. The interest in these molecules was stimulated, at least in part, due to their possible significance as models to study conformations of biologically important compounds such as cyclic- $3^{\prime}, 5^{\prime}$ nucleoside monophosphates and also cyclic nucleotides (e.g. cAMP) which contain a dioxaphosphorinane moiety and play important roles in hormone action and cell communication [63-67]. The conformation of the latter compounds is an important issue in view of their function as secondary messengers in cell physiology, and their stereochemically-dependent interactions with intracellular targets. Since 2-oxo-dioxaphosphorinanes tend to be crystalline solids, a systematic study of the effect of substituent groups on the conformation of the ring have been carried out by X-ray diffraction [59, 68, 69]. Substituent effects have also been studied by NMR [70-74] and dipole measurements [75].

\section{Experimental}

Synthesis

(4S)-2-Chloro-4-methyl-1,3,2-dioxaphosphorinane (CMDOP) was obtained from $(S)$-(+)-butane-1,3-diol and $\mathrm{PCl}_{3}$ in $\mathrm{CH}_{2} \mathrm{Cl}_{2}$ as solvent [76]. Yield of distilled product 58\%. ${ }^{31} \mathrm{P}$ NMR (diethyl ether) $\delta=151.0 \mathrm{ppm}$.

(4S)-2-Methoxy-4-methyl-1,3,2-dioxaphosphorinane (MMDOP). Into the solution of the CMDOP $(0.9 \mathrm{~g}$, $5.8 \mathrm{mmol})$ in diethyl ether $(6 \mathrm{~mL})$ was added the mixture of anhydrous methanol $(0.19 \mathrm{~g}, 5.8 \mathrm{mmol})$ and triethylamine $(0.7 \mathrm{~g}, 15 \%$ excess $)$ at $-5{ }^{\circ} \mathrm{C}$. The resulting mixture was stirred at room temperature for $10 \mathrm{~min}$ and the precipitated hydrochloride was filtered off. The solution was concentrated to give crude product $(0.6 \mathrm{~g}, 69 \%)$. This was used for further reactions without purification. ${ }^{31} \mathrm{P}$ NMR $\delta=129.3 \mathrm{ppm}$ (trans-isomer, $70 \%), \delta=133.0 \mathrm{ppm}$ (cisisomer, $30 \%$ ). The analogous reaction performed in the presence of $20 \%$ excess triethylamine at $-10{ }^{\circ} \mathrm{C}$ gave the mixture of $85 \%$ cis- and $15 \%$ trans-isomers.

(4S)-2-Triphenylmethyl-2-oxo-4-methyl-1,3,2-dioxaphosphorinane. Trityl chloride $(1.1 \mathrm{~g}, 4 \mathrm{mmol})$ and the MMDOP $(0.6 \mathrm{~g}, 4 \mathrm{mmol}, 70 \%$ trans $)$ in dry acetonitrile $(6 \mathrm{~mL})$ was heated at reflux for $15 \mathrm{~min}$. The solvent was evaporated and the residue was crystallized from diethyl ether to give $0.9 \mathrm{~g}$ of the product containing $87.5 \%$ of the trans-isomer (2a) and $12.5 \%$ of the cis-isomer (1b). Analogous reaction with $85 \%$ cis-phosphite gave the mixture containing $83 \%$ cis-isomer (1a) and $17 \%$ transisomer (2b).

The mixtures were separated chromatographically on the silica gel (chloroform-diethyl ether-ethyl acetate, 50:40:2; trans $\mathrm{R}_{\mathrm{F}} 0.23$, cis $\mathrm{R}_{\mathrm{F}} 0.15$ ). The pure cis-isomers (1a and 1b) were crystallized from acetonitrile (about $\left.5 \mathrm{~cm}^{3}\right)$ at ambient temperature. Each of the trans-isomers (2a and 2b) was crystallized from about $6 \mathrm{~cm}^{3}$ of acetone at room temperature. In all cases the crystal grow after $3-6 \mathrm{~h}$.

\section{NMR Spectra}

NMR experiments were performed in Varian VXR $200 \mathrm{MHz}$. Final compounds were dissolved in $\mathrm{CDCl}_{3}$, $\mathrm{C}_{6} \mathrm{D}_{6}$ and $\mathrm{C}_{5} \mathrm{D}_{5} \mathrm{~N}$ deuterated solvents. Chemical shifts were reported in ppm relative to TMS for ${ }^{1} \mathrm{H},{ }^{13} \mathrm{C}$ NMR spectra and to $85 \% \mathrm{H}_{3} \mathrm{PO}_{4}$ in $\mathrm{H}_{2} \mathrm{O}$ for ${ }^{31} \mathrm{P}$ NMR spectra. Crystalline samples were used for solid state NMR measurements. The solid-state CP MAS NMR experiments were performed on above mentioned spectrometer, equipped with an MAS probehead using $4 \mathrm{~mm} \mathrm{ZrO}_{2}$ rotors. The NMR data are given in Tables 1, 23.

Table $1{ }^{1} \mathrm{H}$ NMR chemical shifts for tritylphosphonates $\mathbf{1}$ and $\mathbf{2}$ in solution at $298 \mathrm{~K}$

\begin{tabular}{llllllll}
\hline Compound & Solvent & $\delta \mathrm{A}$ & $\delta \mathrm{B}$ & $\delta \mathrm{C}$ & $\delta \mathrm{D}$ & $\delta \mathrm{E}$ & $\delta \mathrm{F}$ \\
\hline Cis-1 & $\mathrm{CDCl}_{3}$ & 3.73 & 4.34 & 1.65 & 2.11 & 3.67 & 1.29 \\
& $\mathrm{C}_{6} \mathrm{D}_{6}$ & 3.09 & 3.73 & 0.69 & 1.43 & 3.29 & 0.88 \\
\multirow{2}{*}{ Trans-2 } & $\mathrm{CDCl}_{3}$ & 4.54 & 4.08 & $1.50^{\mathrm{a}}$ & 1.50 & 4.78 & 1.08 \\
& $\mathrm{C}_{6} \mathrm{D}_{6}$ & 4.13 & 3.39 & 0.56 & 1.10 & 4.37 & 0.64 \\
\hline
\end{tabular}

${ }^{a}$ Precise values were not determined due to isochronicity of protons $\mathrm{C}$ and D 
Table $2{ }^{13} \mathrm{C}$ NMR chemical shifts of $\mathbf{1 a}, \mathbf{b}$ and $\mathbf{2 a}, \mathbf{b}$ in solution and in solid state

\begin{tabular}{lllllllll}
\hline Compound & Solvent conditions & $\delta \mathrm{Me}$ & $\delta \mathrm{C} 4$ & $\delta \mathrm{C} 5$ & $\delta \mathrm{C} 6$ & $\delta \mathrm{CP}^{\mathrm{a}}$ & $\delta \mathrm{C}^{\prime}$ & $\delta \mathrm{C}^{\prime}, 3^{\prime}, 4^{\prime}$ \\
\hline Cis-1 & $\mathrm{CDCl}_{3}$ & $22.8(8.7)$ & $76.4(8.8)$ & $33.1(12.0)$ & $66.8(8.4)$ & $63.8(136.0)$ & $141.4(5.3)$ & $130.9(6.7) ; 127.9 ; 127.0(1.7)$ \\
& Solid, racemic 1b & 22.5 & 76.6 & $33.1^{\mathrm{a}}$ & $69.1^{\mathrm{a}}$ & $64.2(135.0)$ & 141.0 & $127.6 ; 130.0^{\mathrm{a}}$ \\
& Solid 1a (4S, Rp) & 22.2 & 76.2 & 33.0 & 70.3 & $64.7(136.0)$ & $142.3 ; 139.4$ & $141.4 ; 125.8-132.2^{\mathrm{b}}$ \\
\multirow{3}{*}{ Trans-2 } & $\mathrm{CDCl}_{3}$ & $22.3(8.0)$ & $73.5(7.4)$ & $32.9(5.1)$ & $65.3(7.4)$ & $62.8(135.0)$ & $141.2(5.4)$ & $130.9(6.6) ; 127.9 ; 127.0(1.8)$ \\
& Solid, racemic 2a & 22.7 & 73.6 & $32.8^{\mathrm{a}}$ & $\mathrm{c}$ & $63.9(134.0)$ & $141.1^{\mathrm{d}}$ & $127.7 ; 132.3$ \\
& Solid 2b (4S, Sp) & 21.5 & 74.0 & $32.5-36.0^{\mathrm{a}}$ & $66.5^{\mathrm{a}}$ & $63.5(135.0)$ & $140.3 ; 140.9^{\mathrm{e}}$ & $126.0-134.0^{\mathrm{f}}$ \\
& & 25.6 & & & & $63.9(135.0)$ & $142.0 ; 144.0$ & \\
\hline
\end{tabular}

\footnotetext{
${ }^{a}$ Broad signal

b Three ill resolved signals

c Signal not observed

d Line width

e Two doublets

${ }^{f}$ Relative intensity $1: 1: 3: 1$
}

Table $3{ }^{1} \mathrm{H}-{ }^{1} \mathrm{H}$ coupling constants for tritylphosphonates $\mathbf{1}$ and $\mathbf{2}$ in solution at $297 \mathrm{~K}$

\begin{tabular}{|c|c|c|c|c|c|c|c|c|c|c|c|c|c|c|}
\hline Compound & Solvent & $J_{\mathrm{AB}}$ & $J_{\mathrm{AC}}$ & $J_{\mathrm{BC}}$ & $J_{\mathrm{CD}}$ & $J_{\mathrm{BD}}$ & $J_{\mathrm{CE}}$ & $J_{\mathrm{DE}}$ & $J_{\mathrm{AD}}$ & $J_{\mathrm{BP}}$ & $J_{\mathrm{EP}}$ & $J_{\mathrm{CP}}$ & $J_{\mathrm{DP}}$ & $J_{\mathrm{EF}}$ \\
\hline \multirow[t]{3}{*}{ Cis $-\mathbf{1}$} & $\mathrm{C}_{6} \mathrm{D}_{6}$ & 10.7 & 3.7 & 4.5 & 14.2 & 4.7 & 3.6 & 9.3 & 9.8 & 9.1 & 8.0 & 2.6 & 1.5 & 6.3 \\
\hline & $\mathrm{CDCl}_{3}$ & 10.8 & 3.7 & 3.5 & 14.7 & 4.8 & 3.0 & 9.8 & 8.7 & 9.8 & 6.0 & 3.0 & 1.1 & 6.3 \\
\hline & $P y-d_{5}$ & 10.6 & 3.7 & 4.4 & 14.3 & 4.9 & 3.9 & 9.3 & 9.2 & 10.3 & 7.6 & 2.8 & 1.3 & 6. \\
\hline \multirow[t]{2}{*}{ Trans-2 } & $\mathrm{C}_{6} \mathrm{D}_{6}$ & 11.2 & 2.4 & 2.0 & 14.3 & 4.6 & 2.8 & 11.2 & 2.4 & 20.3 & 1.1 & 2.4 & 1.0 & \\
\hline & $\mathrm{CDCl}_{3}$ & 10.6 & $\mathrm{a}$ & 3.0 & $\mathrm{a}$ & 4.0 & $\mathrm{a}$ & $\mathrm{a}$ & 2.7 & 19.6 & 1.1 & $\mathrm{a}$ & $\mathrm{a}$ & \\
\hline
\end{tabular}

${ }^{a}$ Coupling constant has been not determined due to isochronicity of protons $\mathrm{C}$ and $\mathrm{D}$, resulting in virtual coupling, complicating the multiplets $\mathrm{A}$ and $\mathrm{C}$

\section{X-ray Crystallography}

Colourless rectangular prism shape crystals of 4-methyl-2oxo-2-trityl-1,3,2-dioxaphosphorinane were mounted in turn on a KM-4 automatic four-circle diffractometer equipped with proportional counter detector, and used for data collection. X-ray intensity data were collected with graphite monochromated $\mathrm{Cu} K \alpha$ or $\operatorname{Mo} K \alpha$ radiation (Table 2), with $\omega-2 \theta$ scan mode. The unit cells parameters were determined from least-squares refinement of the setting angles of 99 strong reflections. Details concerning crystal data and refinement are given in Table 4. Examination of three reflections monitored after each 100 measured reflections showed no loss of the intensity for all measurements. Lorentz, polarization, and numerical absorption [77] corrections were applied. The structures were solved by direct methods. All the non-hydrogen atoms were refined anisotropically using full-matrix, leastsquares technique on $F^{2}$. All the hydrogen atoms were found from difference Fourier synthesis after four cycles of anisotropic refinement, and refined as "riding" on the adjacent atom with individual isotropic displacement factor equal 1.2 times the value of equivalent displacement factor of the parent atoms. The hydrogen atom positions were idealised after each cycle of refinement. The methyl groups were allowed to rotate about their local three-fold axes. The methyl group of 2a shows static disorder over two positions of $\mathrm{C}_{3} \mathrm{O}_{2} \mathrm{P}$ ring. The refinement of this disorder model with occupation parameters free to refine (the sum of the both parameters was constrained to be 1) leads to 0.527(18) : 0.473(18) participation of domains in final refinement cycle. The SHELXS97 [78], SHELXL97 [79] and SHELXTL [80] programs were used for all the calculations. Atomic scattering factors were those incorporated in the computer programs. Selected interatomic bond distances and angles are listed in Table 5, and geometrical parameters of intermolecular interactions are listed in Table 6.

\section{Results and Discussion}

In the solid state the 4-methyl-2-oxo-2-trityl-1,3,2-dioxaphosphorinane exists in four forms: two $(\mathbf{1 a}, \mathbf{1 b})$ adopting formal cis configuration (1) and two (2a, 2b) possessing a 
Table 4 Crystal data and structure refinement details for studied compounds

\begin{tabular}{|c|c|c|c|c|}
\hline Compound & 1a & $1 \mathbf{b}$ & $\mathbf{2 a}$ & $2 \mathbf{b}$ \\
\hline $\begin{array}{l}\text { Crystal system, space } \\
\text { group }\end{array}$ & Trigonal, $P 3_{2}$ (No. 145) & $\begin{array}{l}\text { Orthorhombic, } P c a 2_{1} \\
\text { (No. 29) }\end{array}$ & Monoclinic, $C c$ (No. 9) & Triclinic, $P 1$ (No. 1) \\
\hline Wavelength & $\lambda(\mathrm{CuK} \alpha)=1.54179$ & $\lambda(\mathrm{MoK} \alpha)=0.71069$ & $\lambda(\operatorname{MoK} \alpha)=0.71073$ & $\lambda(\mathrm{CuK} \alpha)=1.54178$ \\
\hline \multirow{6}{*}{ 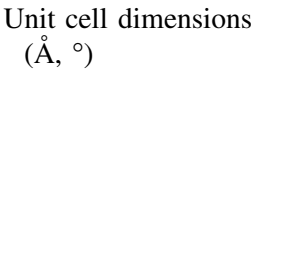 } & $a=8.7820(10)$ & $a=16.773(3)$ & $a=16.133(3)$ & $a=8.397(2)$ \\
\hline & $b=8.7820(10)$ & $b=8.491(1)$ & $b=8.388(2)$ & $b=9.003(2)$ \\
\hline & $c=21.680(4)$ & $c=27.006(5)$ & $c=16.158(3)$ & $c=14.944(3)$ \\
\hline & $\alpha=90.00$ & $\alpha=90.00$ & $\alpha=90.00$ & $\alpha=80.76(3)$ \\
\hline & $\beta=90.00$ & $\beta=90.00$ & $\beta=117.20(3)$ & $\beta=74.38(2)$ \\
\hline & $\gamma=120.00$ & $\gamma=90.00$ & $\gamma=90.00$ & $\gamma=63.31(2)$ \\
\hline Volume $\left(\AA^{3}\right)$ & $1448.0(4)$ & $3846.2(11)$ & $1944.8(9)$ & $971.1(4)$ \\
\hline $\begin{array}{l}\text { Z, Calculated density } \\
\left(\mathrm{Mg} / \mathrm{m}^{3}\right)\end{array}$ & $3,1.302$ & $8,1.307$ & $4,1.292$ & $2,1.294$ \\
\hline $\begin{array}{l}\text { Absorption coefficient } \\
\left(\mathrm{mm}^{-1}\right)\end{array}$ & 1.424 & 0.164 & 0.162 & 1.416 \\
\hline$F(000)$ & 600 & 1600 & 800 & 400 \\
\hline Crystal size (mm) & $0.107 \times 0.099 \times 0.093$ & $0.036 \times 0.027 \times 0.022$ & $0.118 \times 0.109 \times 0.100$ & $0.126 \times 0.093 \times 0.079$ \\
\hline $\begin{array}{l}\theta \text { range for data } \\
\text { collection }\left(^{\circ}\right)\end{array}$ & $5.82-74.89$ & $1.51-25.00$ & $2.81-25.02$ & $3.07-74.91$ \\
\hline Index ranges & $\begin{array}{c}0 \leq h \leq 10,-10 \leq k \leq 9 \\
-27 \leq l \leq 26\end{array}$ & $\begin{array}{l}-11 \leq h \leq 19,-10 \leq k \leq 10 \\
-32 \leq l \leq 32\end{array}$ & $\begin{array}{c}-19 \leq h \leq 19,-9 \leq k \leq 9 \\
-19 \leq l \leq 10\end{array}$ & $\begin{array}{l}-10 \leq h \leq 10,-11 \leq k \leq 10, \\
-18 \leq 1 \leq 18\end{array}$ \\
\hline $\begin{array}{l}\text { Reflections collected/ } \\
\text { unique }\end{array}$ & $\begin{array}{l}6043 / 3824 \\
{\left[\mathrm{R}_{(i n t)}=0.0198\right]}\end{array}$ & $\begin{array}{l}18152 / 6660 \\
\quad\left[\mathrm{R}_{(i n t)}=0.0114\right]\end{array}$ & $\begin{array}{l}5010 / 3422 \\
\quad\left[\mathrm{R}_{(i n t)}=0.0419\right]\end{array}$ & $8002 / 8002\left[\mathrm{R}_{(i n t)}=0.000\right]$ \\
\hline Completeness & $100 \%$ to $\theta=67^{\circ}$ & $99 \%$ to $\theta=25^{\circ}$ & $100 \%$ to $\theta=25^{\circ}$ & $100 \% \theta=67^{\circ}$ \\
\hline $\begin{array}{l}\text { Min. and max. } \\
\text { transmission }\end{array}$ & 0.856 and 0.869 & 0.994 and 1.000 & 0.977 and 0.985 & 0.863 and 0.872 \\
\hline $\begin{array}{l}\text { Data/restraints/ } \\
\text { parameters }\end{array}$ & $3824 / 1^{\mathrm{a}} / 246$ & $6660 / 1^{\mathrm{a}} / 487$ & $2084 / 2^{\mathrm{a}} / 256$ & $8002 / 3^{\mathrm{a}} / 490$ \\
\hline Goodness-of-fit on $F^{2}$ & 1.042 & 1.035 & 1.056 & 1.099 \\
\hline $\begin{array}{l}\text { Final } R \text { indices } \\
\quad(I>2 \sigma(I))\end{array}$ & $\begin{array}{l}R 1=0.0287 \\
\quad w R 2=0.0802\end{array}$ & $R 1=0.0197, w R 2=0.0557$ & $\begin{array}{l}R 1=0.0464 \\
\quad w R 2=0.1130\end{array}$ & $R 1=0.0390, w R 2=0.1236$ \\
\hline$R$ indices (all data) & $\begin{array}{l}R 1=0.0288 \\
\quad w R 2=0.0803\end{array}$ & $R 1=0.0267, w R 2=0.0641$ & $\begin{array}{l}R 1=0.0610 \\
\quad w R 2=0.1240\end{array}$ & $R 1=0.0392, w R 2=0.1238$ \\
\hline Flack parameter & $0.015(13)$ & $0.004(6)$ & $0.005(16)$ & $0.03(2)$ \\
\hline $\begin{array}{l}\text { Largest diff. peak and } \\
\text { hole }\left(\mathrm{e} \AA^{-3}\right)\end{array}$ & 0.183 and -0.166 & 0.258 and -0.239 & 0.158 and -0.350 & 0.365 and -0.277 \\
\hline
\end{tabular}

Data common for all compounds: empirical formula $-\mathrm{C}_{23} \mathrm{H}_{23} \mathrm{O}_{3} \mathrm{P}$; formula weight $=378.38 \mathrm{~g} / \mathrm{mol}$; measurement temperature $=291.0(3) \mathrm{K}$; refinement method-full-matrix least-squares on $F^{2}$

${ }^{a}$ Floating origin restraints

formal trans conformation (2). All these forms crystallise in non-centrosymmetric space groups, but only $\mathbf{1 a}$ and $\mathbf{2 b}$ are chiral (Table 4). The crystals of $\mathbf{1 b}$ and $\mathbf{2 a}$ contain internal glide planes what leads to racemic compounds. Additionally, the methyl group of $\mathbf{2 a}$ is disordered over two sites (with almost equal participation of domains), what also leads to conclusion that, from a strict point of view, the asymmetric unit of $\mathbf{2 a}$ contains a racemate. The chiral centres $\mathrm{P} 1$ and $\mathrm{C} 1$ have different configuration in $\mathbf{1}$ and the same configuration in $\mathbf{2}$, and for chiral crystals $\mathbf{1 a}$ and $\mathbf{2 b}$ it is $\mathrm{R}, \mathrm{S}$ and $\mathrm{S}, \mathrm{S}$ respectively. The forms $\mathbf{1 b}$ and $\mathbf{2 b}$ posses two molecules located in the asymmetric unit, while asymmetric unit of $\mathbf{1 a}$ and $\mathbf{2 a}$ is occupied by only one molecule. In both cases of the doubled asymmetric unit content, both molecules posses the same configuration of chiral centres. 


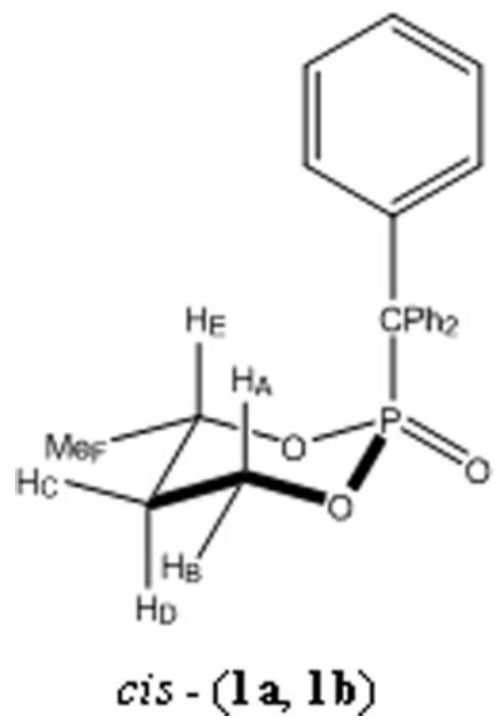

Six-membered rings possess twelve potential symmetry elements which must be considered in order to determine the solid state conformation of the ring, and this can be done by calculation of two types of asymmetry parameters [81]:

$$
\Delta C_{2}=\sqrt{\frac{\sum_{i=1}^{m}\left(\varphi_{i}-\varphi_{i}^{\prime}\right)^{2}}{m}} \text { for twofold axis, and } \Delta C_{s}=
$$
$\sqrt{\frac{\sum_{i=1}^{m}\left(\varphi_{i}+\varphi_{i}^{\prime}\right)^{2}}{m}}$ for mirror plane, where $\mathrm{m}$ is the number of the symmetrical pairs of the torsion angles and the $\phi_{i}$ and $\varphi_{i}^{\prime}$ are values of the symmetry-dependent torsion angles taken into account. Placement of asymmetry parameters for the solid state determined compounds (1a, 1b, 2a, 2b) is shown in Fig. 1. The most preferred conformation of the puckered heteroatom rings is the half-chair slightly distorted toward sofa (rings of 1a, $2 \mathbf{a}$ and $\mathbf{2} \mathbf{b}$ containing P1 atom). The other three rings exhibit half-chair, sofa and sofa strongly distorted toward half-chair conformations, respectively for $\mathbf{1 b}$ (ring containing P1 atom), 2b (ring containing P51 atom) and $\mathbf{1 b}$ (ring containing P51 atom). The study of solid state conformations of the structurally characterised dioxaphosphorinanes found in Cambridge Structure Database [82] (112 compounds) shows that the most preferred conformation is a distorted one between sofa and twist (72 structures) and the second most populated conformation is the transition one between sofa and half-chair ( 32 structures). The studied compounds represent mainly the less preferred conformations (the mixed one: sofa/half-chair) and two rings exhibit rare, almost ideal sofa or nearly perfect half-chair conformation. The total puckering amplitude [83] of the studied heteroatomic six-membered rings falls in the range 0.470 (1b) -0.525 (2b) with $\theta \subset<16.74-168.11^{\circ}>$ and $\varphi \subset<$ $15.13-339.83^{\circ}>$.

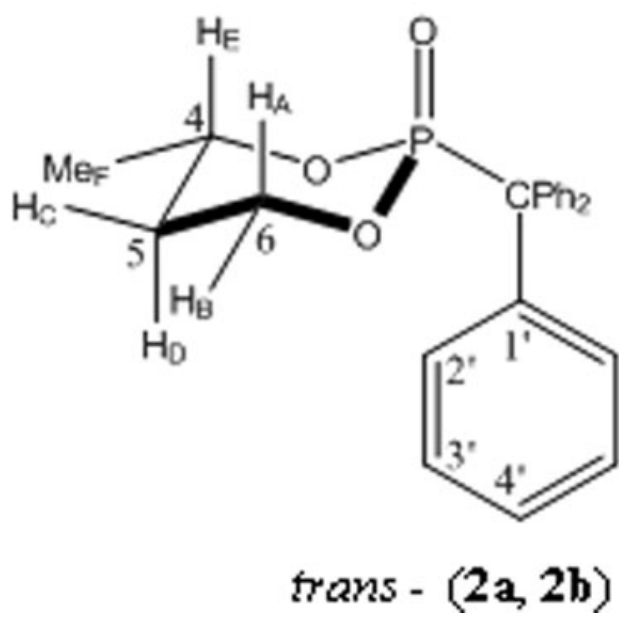

There are no classical hydrogen bonds in the structures of 4-methyl-2-oxo-2-trityl-1,3,2-dioxaphosphorinane due to the absence of hydrogen bonds donors (Figs. 2, 3, 4, 5), however some intermolecular $\mathrm{C}-\mathrm{H} \cdots \mathrm{O}$ short contacts (Table 6) can be classified as weak hydrogen bonds [84, 85]. Additionally, stacking interactions between aromatic rings of studied compounds do not exist.

Beside the structural analysis, the conformation of discussed cyclic derivatives can be the most conveniently deduced from the angular dependence of the magnitude of ${ }^{1} \mathrm{H}-{ }^{1} \mathrm{H},{ }^{1} \mathrm{H}-{ }^{31} \mathrm{P}$ and ${ }^{13} \mathrm{C}-{ }^{31} \mathrm{P}$ vicinal coupling constants. However, frequently the question arises whether the conformation in the solid state corresponds to the one found in the solution. ${ }^{13} \mathrm{C}$ and ${ }^{31} \mathrm{P}$ CP-MAS NMR technique provides means of verifying this point by the comparison of the chemical shifts of signals in the solution and the solid state spectra. In addition the line multiplicity in MAS NMR can serve as a means of detection of multiple conformations or crystallographically nonequivalent molecules in the solid lattice. In present case, the ${ }^{13} \mathrm{C}$ SS NMR (crystalline form) racemic isomer cis-1b shows existence of three nonequivalent (conformationally) molecules, but only one molecule for the crystalline form of enantiomerically pure compound (cis-1a). Racemic isomer trans-2a in crystalline form demonstrates rather broad spectrum indicating an existence of a few nonequivalent molecules or a significant portion of disorder in the lattice. Enantiomeric form cis-1a shows existence of two nonequivalent molecules $(1: 1)$.

The conformation of 2-oxo-1,3,2-dioxaphosphorinane ring system was found to depend on the nature and on the bulkiness of the ring substituents [86]. In general the electron-withdrawing substituents with their known preference for axial position were found to enhance the 
Table 5 Selected structural data for studied compounds $\left(\AA{ }^{\circ}\right)$

\begin{tabular}{lllll}
\hline & Cis-1a & Cis-1b & Trans-2a & Trans-2b \\
\hline O1-P1 & $1.5762(11)$ & $1.570(6)$ & $1.563(3)$ & $1.575(2)$ \\
O2-P1 & $1.5771(12)$ & $1.43(3)$ & $1.566(3)$ & $1.582(2)$ \\
O3-P1 & $1.4643(12)$ & $1.552(4)$ & $1.466(3)$ & $1.463(2)$ \\
P51-O51 & - & $1.565(16)$ & - & $1.571(2)$ \\
P51-O52 & - & $1.47(3)$ & - & $1.580(3)$ \\
P51-O53 & - & $1.575(14)$ & - & $1.462(3)$ \\
O3-P1-O1 & $112.02(7)$ & $105.32(15)$ & $113.7(2)$ & $113.48(14)$ \\
O3-P1-O2 & $113.35(7)$ & $112.6(14)$ & $114.2(2)$ & $114.13(16)$ \\
O1-P1-O2 & $106.31(7)$ & $113.7(13)$ & $104.60(18)$ & $104.27(13)$ \\
O51-P51-O52 & - & $114.2(17)$ & - & $104.87(14)$ \\
O51-P51-O53 & - & $105.6(4)$ & - & $114.44(16)$ \\
O52-P51-O53 & - & $112.0(11)$ & - & $113.88(17)$ \\
P1-O1-C1-C2 & $-41.60(18)$ & $-6.73(12)$ & $53.83(7)$ & $-58.93(4)$ \\
O1-C1-C2-C3 & $61.7(2)$ & $42.58(19)$ & $-59.46(8)$ & $59.78(4)$ \\
C1-C2-C3-O2 & $-50.58(2)$ & $-58.04(11)$ & $54.93(7)$ & $-54.94(5)$ \\
C2-C3-O2-P1 & $16.33(2)$ & $38.28(7)$ & $-45.43(6)$ & $48.35(5)$ \\
C3-O2-P1-O1 & $4.53(16)$ & $-4.72(17)$ & $35.83(4)$ & $-41.9(3)$ \\
O2-P1-O1-C1 & $9.49(11)$ & $-12.15(6)$ & $-39.72(5)$ & $46.7(3)$ \\
P51-O51-C51- & - & $-17.85(7)$ & - & $-47.44(5)$ \\
C52 & & & & \\
O51-C51-C52- & - & $50.95(8)$ & - & $57.5(5)$ \\
C53 & & & & $-58.2(5)$ \\
C51-C52-C53- & - & $-58.95(8)$ & - & $45.34(4)$ \\
O52 & & & & $-29.4(3)$ \\
C52-C53-O52- & - & $35.07(8)$ & - & $31.96(4)$ \\
P51 & & & & \\
C53-O52-P51- & - & $-5.05(17)$ & - & \\
O51 & & & & \\
O52-P51-O51- & - & $-5.22(15)$ & - & \\
C51 & & & & \\
\hline
\end{tabular}

chair-twist boat equilibrium, but the $\mathrm{MeO}$ substituent in axial position and $t$ - $\mathrm{Bu}$ in equatorial position leads to the chair conformation [87]. On the other hand, the bulky substituent, such as a trityl group at 2-position of the 6,4dimethyl substituted ring, causes significant ring flattening due to steric repulsions [88]. Two bulky ring substituents cause the transition into the boat conformation, as is the case of 2,6-bis-tert-butyl-substituted ring [89].

Unusually large difference in the chemical shifts of ${ }^{31} \mathrm{P}$ atoms, observed for $\mathbf{1}$ and $\mathbf{2}$ solutions (amounting up to $10 \mathrm{ppm}$ in $\mathrm{CDCl}_{3}$ at $273 \mathrm{~K}$ ), shows that three types of conformations of the title compound exist. The ${ }^{1} \mathrm{H}$ NMR spectra were recorded in two different solvents: chloroform- $\mathrm{d}$ and benzene- $\mathrm{d}_{6}$. In deuterated chloroform chemical shifts of protons are in lower field (larger $\delta$ ) than in deuterated benzene because benzene has a strong diamagnetic anisotropy [90] and it causes observed resonance of a given
Table 6 Hydrogen bonds in studied compounds $\left(\AA,^{\circ}\right)$

\begin{tabular}{|c|c|c|c|c|}
\hline & $\mathrm{D}-\mathrm{H}$ & $\mathrm{H} \cdots \mathrm{A}$ & $\mathrm{D} \cdots \mathrm{A}$ & $\mathrm{D}-\mathrm{H} \cdots \mathrm{A}$ \\
\hline \multicolumn{5}{|l|}{ Cis-1a } \\
\hline $\mathrm{C} 7-\mathrm{H} 7 \cdots \mathrm{O} 1$ & 0.93 & 2.42 & $3.155(2)$ & 135.9 \\
\hline $\mathrm{C} 13-\mathrm{H} 13 \cdots \mathrm{O} 3$ & 0.93 & 2.44 & $3.171(2)$ & 136.1 \\
\hline $\mathrm{C} 20-\mathrm{H} 20 \cdots \mathrm{O} 3 \# 1$ & 0.93 & 2.50 & $3.422(2)$ & 171.7 \\
\hline \multicolumn{5}{|l|}{ Cis-1b } \\
\hline 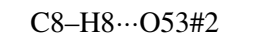 & 1.08 & 2.46 & $3.522(7)$ & 168 \\
\hline $\mathrm{C} 11-\mathrm{H} 11 \cdots \mathrm{O} 1$ & 1.08 & 2.58 & $3.070(3)$ & 107 \\
\hline $\mathrm{C} 17-\mathrm{H} 17 \ldots \mathrm{O} 3$ & 1.08 & 2.30 & $3.148(5)$ & 134 \\
\hline $\mathrm{C} 19-\mathrm{H} 19 \cdots \mathrm{O} 2$ & 1.08 & 2.26 & $3.092(7)$ & 133 \\
\hline 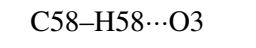 & 1.08 & 2.53 & $3.588(6)$ & 167 \\
\hline C64-H64… O3\#3 & 1.08 & 2.47 & $3.399(11)$ & 143 \\
\hline 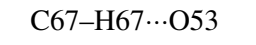 & 1.08 & 2.24 & $3.086(7)$ & 133 \\
\hline C69-H69…052 & 1.08 & 2.25 & $3.098(12)$ & 134 \\
\hline 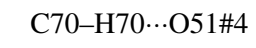 & 1.08 & 2.59 & $3.568(6)$ & 150 \\
\hline \multicolumn{5}{|l|}{ Trans-2a } \\
\hline $\mathrm{C} 11-\mathrm{H} 11 \cdots \mathrm{O} 3$ & 0.93 & 2.46 & $3.192(7)$ & 135.8 \\
\hline $\mathrm{C} 13-\mathrm{H} 13 \cdots \mathrm{O} 2$ & 0.93 & 2.33 & $3.044(5)$ & 133.7 \\
\hline $\mathrm{C} 19-\mathrm{H} 19 \cdots \mathrm{O} 1$ & 0.93 & 2.55 & $3.055(5)$ & 114.1 \\
\hline \multicolumn{5}{|l|}{ Trans-2b } \\
\hline $\mathrm{C} 11-\mathrm{H} 11 \cdots \mathrm{O} 1$ & 0.93 & 2.60 & $3.083(4)$ & 113.1 \\
\hline $\mathrm{C} 13-\mathrm{H} 13 \cdots \mathrm{O} 2$ & 0.93 & 2.37 & $3.078(4)$ & 132.9 \\
\hline C19-H19...O3 & 0.93 & 2.49 & $3.221(5)$ & 136.0 \\
\hline C57-H57…052 & 0.93 & 2.56 & $3.052(4)$ & 113.2 \\
\hline C63-H63‥O53 & 0.93 & 2.41 & $3.151(5)$ & 136.1 \\
\hline C69-H69...O51 & 0.93 & 2.31 & $3.040(4)$ & 135.6 \\
\hline
\end{tabular}

Symmetry transformations used to generate equivalent atoms: $\# 1:+x$, $+y+1,+z ; \# 2:+0.5-z,+y+1,+0.5+z ; \# 3:+0.5+x,-y$, $+z ; \# 4:+0.5+x-1,+y,+0.5+z$

protons to be shifted to a higher field (smaller $\delta$ ). This difference appears to be dependent on the shape of the solvent molecules. Aromatic solvent, such as benzene is flat. There were difficulties to determine precise values of chemical shifts of protons $\mathrm{C}$ and $\mathrm{D}$ due to isochronicity of these signals. The signals of protons $\mathrm{A}$ and $\mathrm{E}$ in compound cis appear in a higher field than in the trans compound because of the influence of the shielding cone of trityl (increasing electron density over benzene rings) and the protons have a smaller chemical shift in the cis conformation than in the trans because there are no other elements which influence the signals.

The observed $\mathrm{H}-\mathrm{H}$ coupling constants in cis-conformation are comparable (or almost identical) in the cases of $\mathrm{J}_{\mathrm{AC}}, \mathrm{J}_{\mathrm{BD}}, \mathrm{J}_{\mathrm{EF}}, \mathrm{J}_{\mathrm{CD}}, \mathrm{J}_{\mathrm{DP}}, \mathrm{J}_{\mathrm{DE}}, \mathrm{J}_{\mathrm{AB}}$. The long range coupling [91] (over more than three bonds) can be observed and it involves relatively small coupling constants like in the case of ${ }^{4} \mathrm{~J}_{\mathrm{DP}},{ }^{4} \mathrm{~J}_{\mathrm{CP}}$ when the conformation is closely related to the conformation of cyclohexane. For compound possessing cis-conformation all coupling constant are well separated 
in all used deuterated solvents. Some coupling constants (like ${ }^{3} J_{\mathrm{BP}}$ one) change with the polarity of the solvent and the solvent dielectric constant [92] (enlargement of this value is accompanied by increased coupling constant). Remaining constants change with the variation of the molecular geometry i.e. changes of interbond angles. Deuterated benzene (like deuterated pyridine), because of the flat shape, may create solute-solvent complexes in a solution, and in consequence they can influence the bonds and interbond angles, which leads to changes in a coupling constants. Deuterated pyridine additionally causes the paramagnetic shift and thus it may also have influence on coupling constants.

The compound possessing the trans-conformation does not produce the coupling constants of $\mathrm{C}$ and $\mathrm{D}$ protons in deuterated chloroform, due to their isochronicity, thus the solvent was changed to the less polar-deuterated benzene. The coupling constants between $\mathrm{AB}, \mathrm{BD}$ and $\mathrm{BP}$ atoms are larger in benzene and between $\mathrm{BC}$ and $\mathrm{AD}$ atoms are smaller due to the conformation of the compound. These couplings are between axial and equatorial protons, and they exist through three bonds. On the basis of Karplus equation (correlation of changes of coupling constant with changes of dihedral angle [93]) it can be stated that two preferable groups of $\mathrm{H}-\mathrm{C}-\mathrm{C}-\mathrm{H}$ torsion angles exist, one

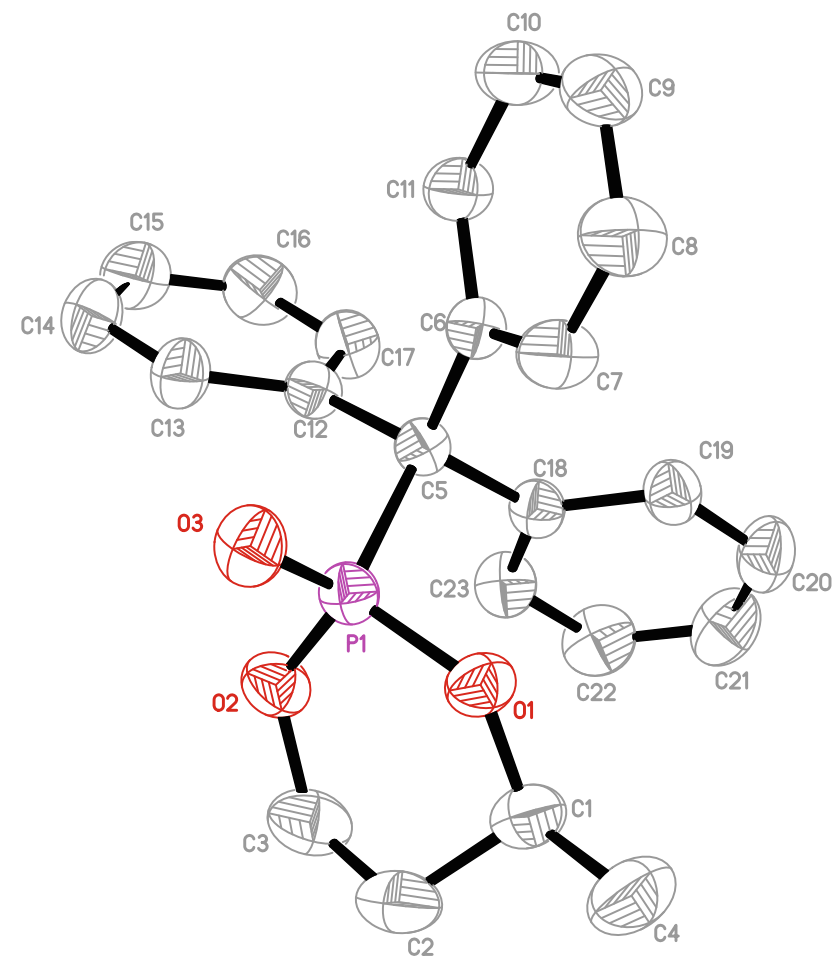

Fig. 2 The molecular conformation of 1a with atom numbering, plotted with $50 \%$ probability of displacement ellipsoids of nonhydrogen atoms. The hydrogen atoms were omitted for clarity

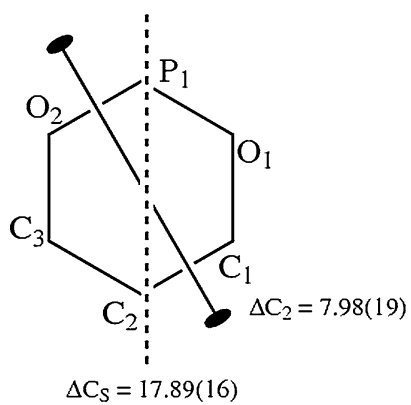

(a)

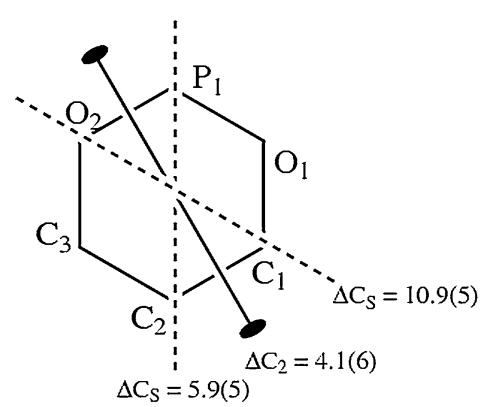

(c)

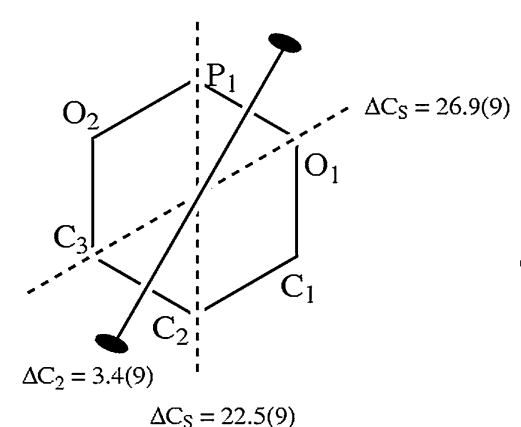

(b)

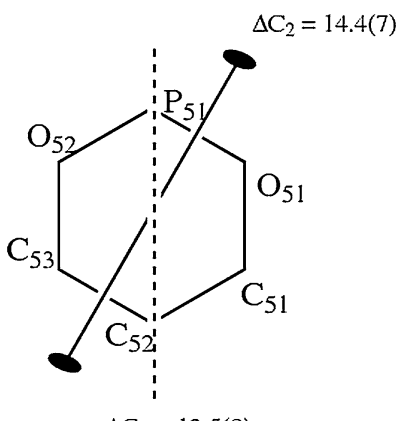

$\Delta \mathrm{C}_{\mathrm{S}}=12.5(8)$

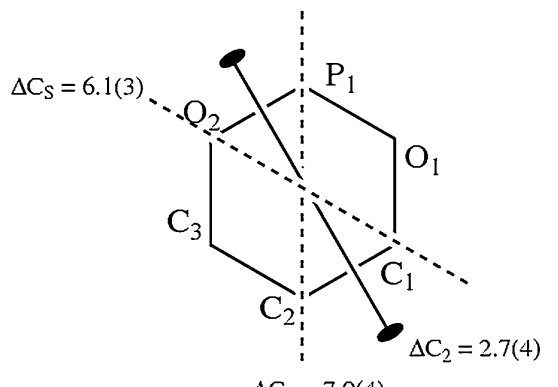

$\Delta \mathrm{C}_{\mathrm{S}}=7.0(4)$

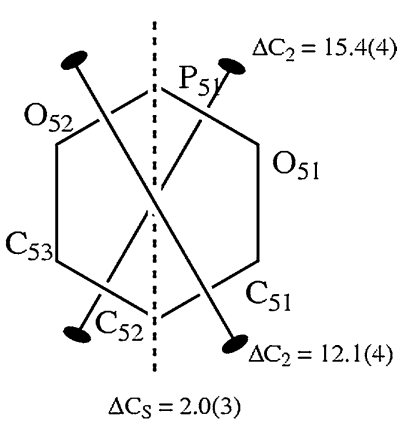

(d)

Fig. 1 Placement and values of the smallest asymmetry parameters for studied compounds: a cis-1a, b cis-1b, c trans-2a and $\mathbf{d}$ trans-2b 
Fig. 3 The molecular conformation of $\mathbf{1 b}$ with atom numbering, plotted with $50 \%$ probability of displacement ellipsoids of non-hydrogen atoms. The hydrogen atoms were omitted for clarity
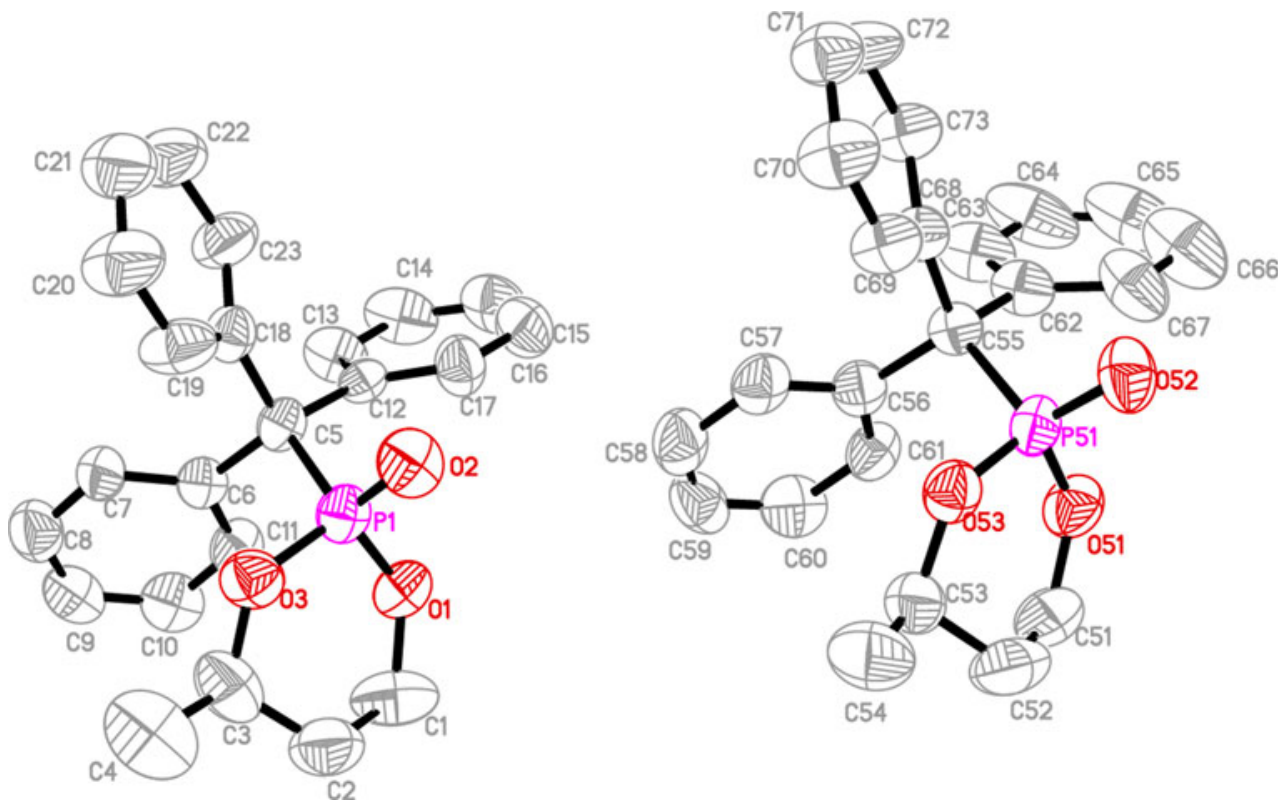

${ }^{13} \mathrm{C}$ NMR spectra were recorded in the solution (deu-

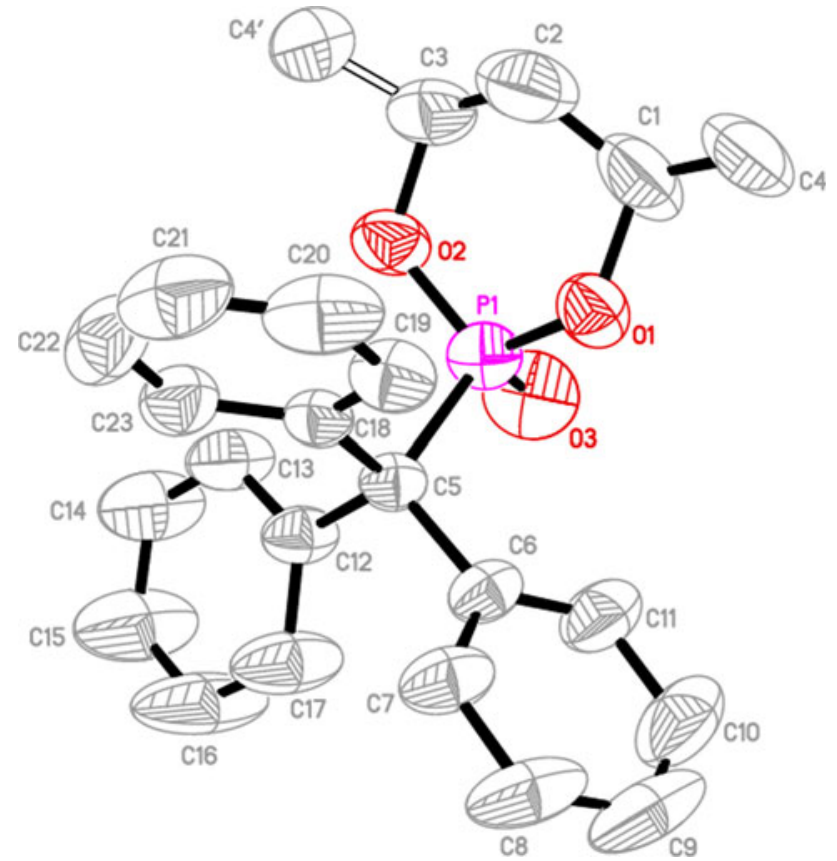

Fig. 4 The molecular conformation of 2a with atom numbering, plotted with $50 \%$ probability of displacement ellipsoids of nonhydrogen atoms. The hydrogen atoms were omitted for clarity. The hollow line and $\mathrm{C}^{\prime}$ atom indicates the disordered methyl group

for $\mathrm{A}-\mathrm{C}, \mathrm{B}-\mathrm{C}, \mathrm{B}-\mathrm{D}$ and $\mathrm{C}-\mathrm{E}$ pairs of protons and second one for DE-AD pairs of protons. The angle near to $60^{\circ}$ gives the coupling constant about $4 \mathrm{~Hz}$ and angle close to $120^{\circ}$ leads to the coupling constant equals about $6 \mathrm{~Hz}$ [91], thus it can be postulated that $\mathrm{H}-\mathrm{C}-\mathrm{C}-\mathrm{H}$ torsion angles of the first mentioned group are slightly larger than $60^{\circ}$, and those ones of second group are about $120-140^{\circ}$. terated chloroform) and in the solid state. In solution the chemical shift of the methyl group and its coupling constants are comparable for both isomers. The similarity of the chemical shift of the $\mathrm{CP}^{\mathrm{a}}$ and aromatic carbon atoms for cis and trans isomers can be also observed. Chemical shift and coupling constants of a $\mathrm{C} 4$ and $\mathrm{C} 6$ atoms in both conformers are different because of the shielding cone of trityl group in the conformers. Noteworthy is the fact that C5 atom chemical shift in both conformers is comparable but the coupling constant in cis-conformer is two times larger than in trans. This can be explained by the Karplus effect. In presented case, the change of the $\mathrm{C}_{2} \mathrm{O}_{2} \mathrm{P}$ ring conformation leads to the alteration of the torsion angles, and in consequence to the different coupling constants.

The ${ }^{13} \mathrm{C}$ CP-MAS NMR spectra recorded for $\mathbf{1 b}$ racemic and 2a racemic 4-methyl-2-oxo-2-trityl-1,3,2-dioxaphosphorinane show that the chemical shifts of the methyl group are comparable just like signals from aromatic carbon atoms. For $\mathrm{C} 5$ atoms the chemical shifts are very similar but the observed signals are broadened in both cases. The signal of $\mathbf{C 6}$ atom of $\mathbf{2 a}$ is unobserved (in $\mathbf{1 b}$ the broad signal appears) probably due to the close presence of the trityl group in this conformation. The chemical shift of $\mathrm{C}^{1}$ ' is comparable in both conformations but in $\mathbf{2 a}$ the broadening of the signal line is observed. Additionally, the signals from $\mathrm{C} 4$ atoms are not observed in both cases.

The ${ }^{13} \mathrm{C}$ CP-MAS NMR spectra recorded for solid 1a and $\mathbf{2 b}$ were similar to these ones recorded without magic angle spinning (the MAS do not average the observed signals), and this fact, in case of $\mathbf{2} \mathbf{b}$, confirms the presence of two different conformations in solid state. In 1a the couplings are not observed thus it can be supposed that 
Fig. 5 The molecular conformation of $\mathbf{2 b}$ with atom numbering, plotted with $50 \%$ probability of displacement ellipsoids of non-hydrogen atoms. The hydrogen atoms were omitted for clarity

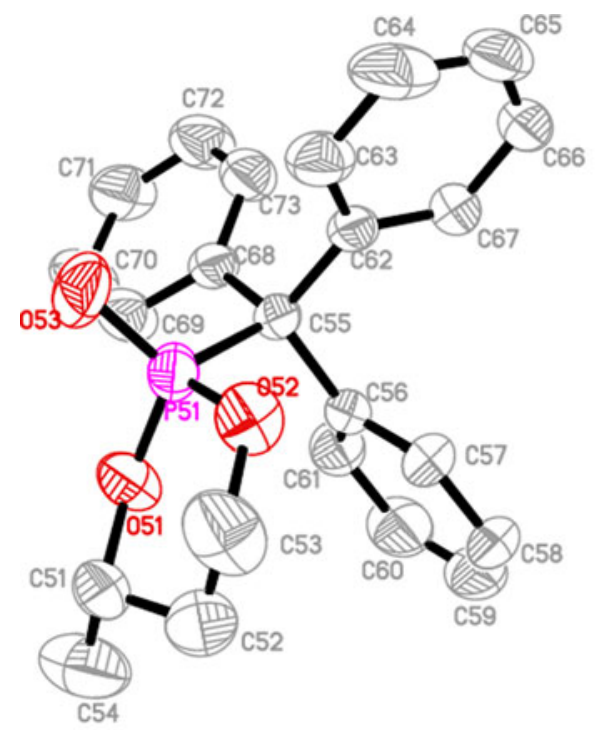

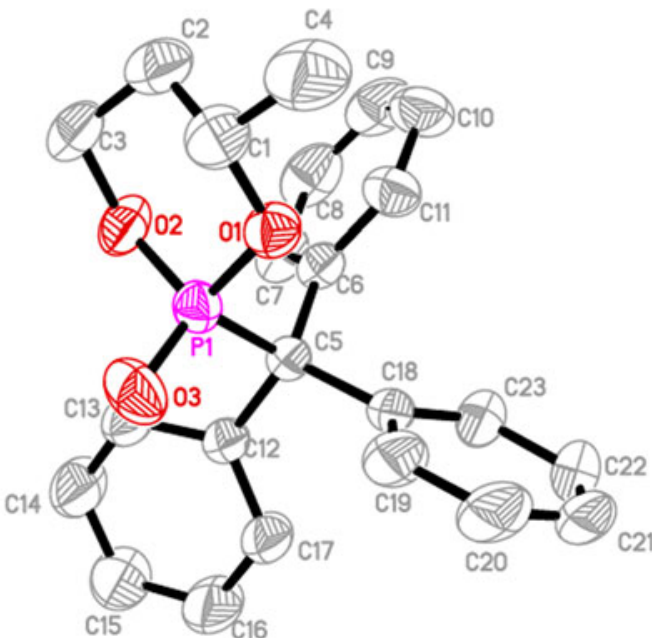

there is only one independent conformation and in the case of aromatic carbon atoms three ill resolved lines related to $\mathrm{C}^{\prime}$ and $\mathrm{C}^{\prime}$ atoms can be found.

In the case of 2a magic angle spinning did not give the signals averaging, thus it can be supposed that there are two conformations due to existence of doublets from methyl group, $\mathrm{CP}^{\mathrm{a}}$ and $\mathrm{C} 1$ signals. Noteworthy is the fact that the signals of $\mathrm{C} 5$ and $\mathrm{C} 6$ atoms are considerably broadened in comparison to those ones observed in ${ }^{13} \mathrm{C} \mathrm{CP}$ MAS NMR spectrum of $\mathbf{1 a}$. The signal originating from $\mathrm{C}^{\prime}$ atoms creates the two doublets and $\mathrm{C}^{\prime}, 3^{\prime}, 4^{\prime}$ atoms signals have the observed relative intensity 1:1:3:1.

\section{Conclusion}

The cis- and trans-2-methyl-2-oxo-2-trityl-1,3,2-dioxaphosphorinanes can be crystallised as pure enantiomers and racemates. In each conformer one of the obtained forms contains two molecules per asymmetric unit (racemic cis and chiral trans). In both cases asymmetric unit contains molecules with two different conformations of the puckered heroatomic ring. The small but essential conformational differences existing for heteromatomic rings do not exhibit fully in NMR spectra, because only for the trans isomer the two noncongruent molecules appear in the spectra. It can be explained by existence of two distinctly different conformations in the trans isomer (sofa and distorted half-chair), while in cis isomer the different conformations show some closeness (all conformations can be described as more or less distorted half-chair).

\section{Supplementary Data}

Tables of crystal data and structure refinement, anisotropic displacement coefficients, atomic coordinates and equivalent isotropic displacement parameters for non-hydrogen atoms, $\mathrm{H}$-atom coordinates and isotropic displacement parameters, bond lengths and interbond angles have been deposited with the Cambridge Crystallographic Data Centre under No CCDC806956, CCDC806957 CCDC806958, CCDC806959, respectively for compounds 1a, 1b, 2a and $\mathbf{2 b}$.

Open Access This article is distributed under the terms of the Creative Commons Attribution Noncommercial License which permits any noncommercial use, distribution, and reproduction in any medium, provided the original author(s) and source are credited.

\section{References}

1. Schlemminger I, Willecke A, Maison W, Koch R, Lützen A, Martens J (2001) J Chem Soc Perkin Trans 1:2804

2. Baylis EK, Campbell CD, Dingwall JG (1984) J Chem Soc Perkin Trans 1:2845

3. Takahashi H, Yoshioka M, Imai N, Onimura K, Kobayashi S (1994) Synthesis 763

4. Demir AS, Tanyeli C, Sesenoglu Ö, Demic S, Evin ÖÖ (1996) Tetrahedron Lett 37:407

5. Sardarian AR, Kaboudin B (1997) Tetrahedron Lett 38:2543

6. Weener JW, Versleijen JPG, Meetsma A, Hoeve W, Lausen AM (1998) Eur J Org Chem 1511

7. Atherton FR, Hall MJ, Hassall CH, Holms SW, Lambert RW, Lloyd J, Ringrose PS (1980) Antimicrob Agents Chemother $18: 897$ 
8. Huber JW, Gilmore WF, Robertsen LW (1975) J Med Chem 18:106

9. Atherton FR, Hassall CH, Lambert RW (1986) J Med Chem 29:29

10. Kametani T, Kigasawa K, Hiiragi M, Wakisaka K, Haga S, Sugi H, Tanigawa H, Suzuki Y, Fukawa K, Irino O, Saita O, Yamabe S (1981) Heterocycles 16:1205

11. Natchev IA (1988) Liebigs Ann Chem 861

12. Mao MK, Franz JE (1991) Synthesis 920

13. Emsley J, Hall D (1976) The chemistry of phosphorus. Harper and Row, London, p 494

14. Maier L, Spörri H (1991) Phosphorus Sulfur Silicon Relat Elem 61:69

15. Huang J, Chen R (2000) Heteroat Chem 11:480

16. Hiratake J, Oda J (1997) Biosci Biotechnol Biochem 61:211

17. Patel DV, Rielly-Gauvin K, Ryono DE (1990) Tetrahedron Lett 31:5587 and 5591

18. Pampliano DL, Rands E, Schaber MD, Mosser SD, Anthony NJ, Gibbs JB (1992) Biochemistry 31:3800

19. Stowasser B, Budt KH, Jian-Qi L, Peyman A, Ruppert D (1992) Tetrahedron Lett 33:6625

20. Sikorski JA, Miller MJ, Braccolino DS, Cleary Dg, Corey SD, Font KJ, Gruys KJ, Han CY, Lin K-C, Pansegrau PD, Ream JE, Shnur D, Shah A, Walker MC (1993) Phosphorus Sulfur Silicon 76:115

21. Smith BA, Carol S, Taylor SJ, Benkovic JS, Hirschmann R (1994) Tetrahedron Lett 35:6853

22. Kafarski P, Wieczorek P, Lejczak B, Gancarz R (1996) Bioorg Med Chem Lett 6:2989

23. Fleish H (1998) Endocr Rev 19:80

24. Fleish H (1999) Prog Mol Subcell Biol 232:197

25. Body JJ, Bartl R, Burckhard P, Delmas PD, Diel IJ, Fleisch H, Kanis JA, Kyle RA, Mundy GR, Peterson AH, Rubens RD (1998) J Clin Oncol 16:3890

26. Ganzhorn AJ, Hoflack J, Pelton PD, Strasser F, Chanal M-C, Pitettre SR (1998) Bioorg Med Chem 6:1865

27. Hiraga T, Williams PJ, Mundy GR, Yoneda T (2001) Cancer Res 61:4418

28. Lee MV, Fong EM, Singer FR, Guenette RS (2001) Cancer Res 61:2602

29. Bubenik M, Rej R, Nguyen-Ba N, Attardo G, Oullet F, Chan L (2002) Bioorg Med Chem Lett 12:3063

30. Jankowski S, Marczak J, Olczak A, Główka ML (2006) Tetrahedron Lett 47:3341

31. Zuo N, Hong-Wu H (2007) Acta Cryst Sect E 63:794

32. Kumar NNA, Chakravarty M, Kumar NS, Sajna KV, Swamy KCK (2009) J Chem Sci 121:23

33. Alabugin IV, Brel VK (1997) Russ Chem Rev 66:205

34. Nishimura T, Hirabayashi S, Hayashi T (2006) J Am Chem Soc 126:2556

35. Ma S, Guo H, Yu F (2006) J Org Chem 71:6634

36. Alabugin IV, Brel VK (1997) Russ Chem 66:205

37. Kumar NNA, Chakravarty M, Kumar NS, Sajna KV, Swamy KCK (2008) Eur J Org Chem 4500

38. Kumar NS, Balarama E, Swamy KCK (2006) Tetrahedron 62:10152

39. Shuster HF, Coppola GM. Allenes in organic synthesis. Wiley, New York, p 247

40. Patois C, Richard L, Savignac P (1990) J Chem Soc Perkin Trans $1: 1577$

41. Cruz-Gregorio S, Rodriguez-Palacios V, Höpfl H, Quintero L, Sartillo-Piscil F (2009) J Org Chem 74:197

42. Killean RCG, Lawrence JL, Maggenis IM (1971) Acta Cryst Sect B 27:189

43. Breuer E, Bannet DM (1977) Tetrahedron Lett 1141

44. Breuer E, Bannet DM (1978) Tetrahedron 34:997
45. Breuer E, Zbajda S, Segall E (1970) Tetrahedron Lett 2203

46. Zbajda S, Breuer E (1979) Experienta 35:851

47. Patois C, Ricard L, Savignac P (1990) J Chem Soc Perkin Trans $1: 1577$

48. Weener J-W, Versleijen JPG, Meetsma A, Hoeve W, Leusen AM (1998) Eur J Org Chem 1511

49. Browning CS, Burrow TE, Farrar TH, Lough AJ (1996) Acta Cryst Sect C 52:652

50. Zhang Y-H, Wang X-H, Liu S, Yao C (2006) Acta Cryst Sect E 62:2620

51. Wu J, Sun W, Xia G, Sun Y (2006) Org Biomol Chem 4:1663

52. Balabanovich AI, Prokopovich VP (2006) J Anal Appl Pyrolysis $76: 169$

53. Nazarov AA, Koroteev MP, Hartinger CG, Keppler BK, Nifant'ev EE (2005) Tetrahedron 61:10943

54. Chakravarty M, Srinivas B, Muthiah C, Swamy KCK (2003) Synthesis 15:2368

55. Kaplan AP, Bartlett PA (1991) Biochemistry 30:8165

56. Nishizuka Y (1984) Nature 308:693

57. Boyd VL, Summers MF, Ludeman SM, Egan W, Zon G, Regan JB (1987) J Med Chem 30:366

58. Miao Z, Zhang J, Cui Z, Wang B, Chen R (2007) Helv Chim Acta 90:1932

59. Sun F-M, Tian M-M, Luo Z-G, Shi D-Q (2005) Acta Cryst Sect E 61:4162

60. Arbuzov A, Zoroastrova VM (1952) Izvestiya Akademii Nauk SSSR, Seriya Khimicheskaya 779

61. Arbuzov A, Zoroastrova VM (1948) Izvestiya Akademii Nauk SSSR, Seriya Khimicheskaya 208

62. Bodkin CL, Simpson P (1972) J Am Chem Soc Perkin Trans Phys Org Chem 14:2049

63. Frank É, Körtvélyesi T, Czugler M, Mucsi Z, Keglevich G (2007) Steroids 72:437

64. Sturm PA, Reist EJ (1982) J Org Chem 47:4367

65. Srivastava PC, Ravankar GR, Robins RK (1984) J Med Chem 27:266

66. Sartillo-Piscil F, Cruz S, Sáncez M, Höpfl H, de Parrodi AC, Quintero L (2003) Tetrahedron 59:4077

67. Miljković DA, Vukojević NS, Hadzić PA, Minić DJ, Hughes NA, Hill MNS (1990) J Chem Soc Perkin Trans 2:1093

68. Beineke TA (1969) Acta Cryst Sect B 25:413

69. Haque M, Caughlan CN, Hargis JH, Bentrude WG (1970) J Chem Soc A 1786

70. Edmundson RS (1964) Tetrahedron 20:2781

71. Edmundson RS, Mitchell EW (1968) J Chem Soc C 2091

72. Tsuboi M, Kuriyagawa F, Matsuo K, Kyugoku Y (1967) Bull Chem Soc Japan 40:1813

73. Edmundson RS, Mitchell EW (1968) J Chem Soc C 3033

74. Edmundson RS (1969) Tetrahedron Lett 1905

75. Kainosho M, Shimozawa T (1969) Tetrahedron Lett 865

76. Lucas WJ, Mitchell FW, Scully CN (1950) J Am Chem Soc 72:5491

77. X-RED (1999) Version 1.18. STOE \& Cie GmbH, Darmstadt

78. Sheldrick GM (1990) Acta Cryst Sect A 46:467

79. Sheldrick GM (1997) SHELXL97. Program for the solution and refinement of crystal structures. University of Gottingen, Gottingen

80. Sheldrick GM (1990) SHELXTL: release 4.1 for siemens crystallographic research systems. Analytical X-ray Instruments Inc., Madison

81. Duax L, Norton DA (1975) Atlas of steroid structure, vol 1. IFI/ Plenum, New York, p 16

82. Allen FH (2002) Acta Cryst B58:380. CSD version 5.32+1 update (November 2010)

83. Cremer D, Pople JA (1975) J Am Chem Soc 97:1354

84. Taylor R, Kennard O (1982) J Am Chem Soc 104:5063 
85. Desiraju GR, Steiner T (1999) The weak hydrogen bond in structural chemistry and biology. Oxford University Press, Oxford

86. Dros AC (1968) Novel chiral 1,3,2-dioxaphosphorinanes. University of Groningen, Groningen, Netherlands, $\mathrm{p} 71$

87. Bentrude WG, Tan H-W, Yee KC (1975) J Am Chem Soc 97:573

88. Drew MGB, Rodgers J (1972) Acta Cryst Sect B 28:924

89. Day RO, Bentrude WG, Yee KC, Setzer WN, Deiters JA, Holmes RR (1984) J Am Chem Soc 106:103
90. Buckhingham AD, Shaefer T, Schneider WG (1960) J Chem Phys 32:1227

91. Macomber RS (1998) A complete introduction to modern NMR spectroscopy. Wiley, New York, p 138

92. Mooney EF (1968) Annual review of NMR spectroscopy. Academic Press, London, p 97

93. Minch MJ (1994) Concepts in magnetic resonance 6:41 